\title{
KARAKTERISTIK MORFOLOGI BAKTERI SIMBION SPONS MENYERUPAI Cribochalina sp DARI PERAIRAN MALALAYANG SULAWESI UTARA
}

\author{
(Characteristics Of Morphology Simbions Bacteria Sponge Resembling to Cribochalina sp \\ from Malalayang Waters of North Sulawesi) \\ Gledys G. Poluan ${ }^{1 *}$,Elvy L. Ginting ${ }^{1}$, Stenly Wullur ${ }^{1}$, \\ Veibe Warouw ${ }^{1}$, Fitje Losung ${ }^{1}$, Meiske Salaki ${ }^{2}$
}

1. Program Studi Ilmu Kelautan, Fakultas Perikanan dan IImu Kelautan, Universitas Sam Ratulangi, Manado.

2. Program Studi Manajemen Sumberdaya Perairan, Fakultas Perikanan dan IImu Kelautan, Universitas Sam Ratulangi, Manado.

*e-mail : gledyspoluan3@gmail.com

\begin{abstract}
Bacteria are found to be highly associated with various marine organisms, such as sponges. Sponges are known as the product of bioactive compounds. However, some of the compounds produced by sponges are obtained by the simbion-bacteria. Therefore this situation enables sponges simbion bacteria to play a major role in producing bioactive compounds that have been isolated from the sponge. The purpose of this study is to isolate and determine the characteristics of morphology of spongy simbion bacteria resembling Cribochalina sp, which was taken from Malalayang waters, North Sulawesi. Sponge simbion bacteria grow on NB media. Initially, a free-breeding colony was being done before bacteria were accrued in the NA media by $2 \%$ sponge broth (patent SID201906301) by means of Strike Plate methods. Based on to this study we had isolate five spongy simbion bacteria that resembling the Cribochalina sp. All five of these isolations have different characteristics of morphology in terms of color, shape, size, and elevation.
\end{abstract}

Keywords : bacteria, isolation, simbionts, sponges

\section{ABSTRAK}

Bakteri banyak dijumpai dengan cara berasosiasi dengan berbagai organisme laut, seperti spons. Spons dikenal sebagai penghasil senyawa bioaktif, akan tetapi sebagian senyawa yang diproduksi spons diduga dihasilkan oleh bakteri yang hidup bersimbion. Hal ini yang memungkinkan bakteri simbion spons memiliki peranan besar dalam menghasilkan senyawa bioaktif yang telah diisolasi dari spons. Tujuan dari penelitian ini adalah untuk mengisolasi dan menentukan karakteristik morfologi bakteri simbion spons menyerupai Cribochalina sp. yang diambil dari perairan Malalayang, Sulawesi Utara. Bakteri simbion spons ditumbuhkan dengan media NB. Selain itu untuk mendapatkan koloni bebas dilakukan pengenceran sebelum bakteri ditumbuhkan pada media NA diperkaya 2\% kaldu spons (paten SID201906301) dengan menggunakan metode cawan gores dan penyebaran. Berdasarkan hasil penelitian ini diperoleh lima isolat bakteri simbion spons menyerupai Cribochalina sp. kelima isolat ini memiliki karakteristik morfologi yang berbeda dalam hal warna, bentuk dan elevasi.

Kata Kunci : bakteri, isolasi, simbion, spons 


\section{PENDAHULUAN}

Bakteri adalah kelompok organisme yang tidak memiliki membran sel. Organisme ini termasuk dalam domain prokariota yang berukuran sangat kecil (mikroskopik), namun memiliki peran besar dalam kehidupan di bumi. Bakteri dapat ditemukan hampir di semua tempat, baik di tanah, air maupun udara, bahkan di dalam tubuh manusia dan bersimbiosis dengan organisme lain atau sebagai agen parasit.

Pertumbuhan bakteri dapat dijumpai hidup dengan cara bersimbiosis dengan berbagai organisme laut bentik, salah satunya adalah spons (Abubakar, dkk. 2011). Pola makan spons yang khas yaitu filter feeder (menghisap dan menyaring) dapat memanfaatkan jasad renik disekitarnya, salah satunya bakteri laut sebagai sumber nutrient yang hidup pada perairan tersebut (Suparno, 2005 dalam Wantania 2016).

Bakteri yang bersimbosis dengan spons mampu menghasilkan senyawa bioaktif yang tidak hanya memberikan informasi mengenai keragaman bakteri dalam struktur komunitas mikroba, tetapi dapat memberikan suatu tahapan dari solusi masalah penyediaan senyawasenyawa bioaktif. Banyak substansi bioaktif yang telah diisolasi dari organisme-organisme perairan laut Manado, di antaranya merupakan senyawa baru. Salah satu dari organismeorganisme tersebut adalah spons (Sulasi, dkk. 2013).

Lee, dkk. (2001) menyatakan bahwa spongs mempunyai kemampuan untuk menghasilkan senyawa bioaktif karena hubungan simbiotik dengan mikroorganisme dalam hal ini bakteri. Hubungan ini merupkan penyediaan nutrisi dengan membantu translokasi metabolisme termasuk nitrifika-si, fiksasi nitrogen, fotosintesis dan mem-bantu pertahanan kimiawi serta berperan dalam biofouling.

Eksplorasi bakteri simbion spons perlu dilakukan. Oleh sebab itu penelitin ini dilakukan untuk mengetahui jenis-jenis bakteri yang berasosiasi dengan spons Chribochalina sp dari Perairan Malalayang, Sulawesi Utara.

\section{METODE PENELITIAN \\ Lokasi Pengambilan Sampel \\ Organisme spons}

Chribochalina sp. yang dari perairan Malalayang, Sulawesi Utara.

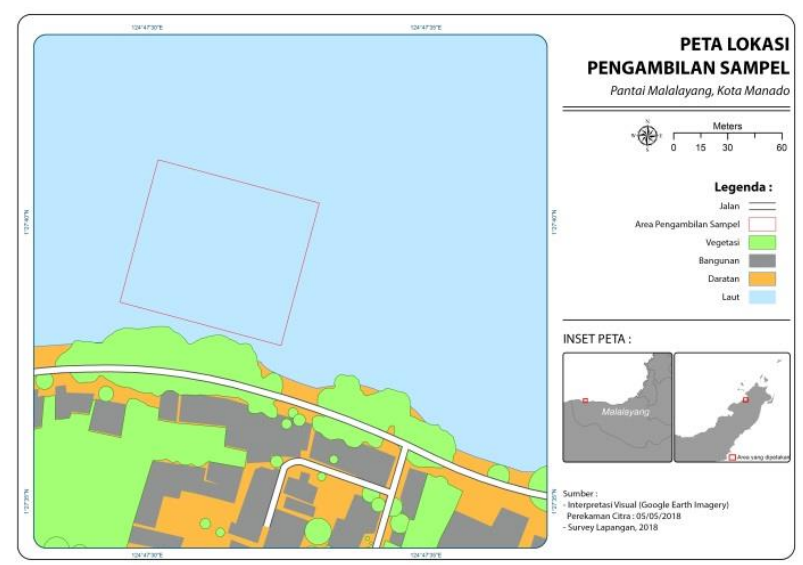

Gambar 1. Peta Lokasi Pengambilan Sampel spons laut di Perairan Malalayang Sulawesi Utara.

$$
\text { Sampel spons diambil dari }
$$

Perairan Malayang Gambar 1. Pengambilan sampel dilakukan dengan menggunakan alat snorkeling pada kedalaman air sekitar 3-5 meter. Pengambilan sampel spons dilakukan dengan cara memotong sampel spons langsung dari substratnya. Sampel dimasukkan ke dalam plastik sampel kemudian disimpan di dalam cool box lalu dibawa ke Laboratorium Biologi Molekuler dan Farmasitika Laut FPIK Unsrat untuk dianalisa.

\section{IDENTIFIKASI SPONS}

Sampel spons yang telah diidentifikasi berdasarkan morfologinya dengan memperhatikan warna dan bentuk. Dan kemudian ditentukan sesuai 
dengan pedoman pada jurnal The Indonesian Sponge Fauna: A Status Report (Van Soest, 1989).

\section{Kultur dan Isolasi Bakteri}

kultur bakteri di tumbuhkan menggunakan media NA diperkaya spons. Dalam penelitian ini dikembangkan dengan nomor paten SID201906301. Pertama-tama disiapkan media NA dengan cara menyiapkan $25 \mathrm{~mL}$ air laut steril ditambah $25 \mathrm{ml}$ aquades dan dicampur dengan bahan $0,5 \mathrm{gr} \mathrm{NB}, 1 \mathrm{gr}$ agar, dan 2\% kaldu spons kedalam Erlenmeyer ukuran $100 \mathrm{ml}$. Erlenmeyer ditutup menggunakan kapas dan dilapisi aluminium foil kemudian di autoklaf pada suhu $121^{\circ} \mathrm{C}$ selama \pm 1 jam. Setelah disterilisasi, secara aseptik media dituang ke dalam cawan petri yang telah steril secara merata, kemudian dibiarkan mengeras. Setelah mengeras dan dingin, dibungkus mengggunakan plastik pembungkus dan diletakkan di inkubator selama $1 \times 24$ jam untuk memastikan tidak terkontaminasi.

Sampel spons dicuci dengan menggunakan air laut steril, caranya masukkan air laut steril ke dalam cawan petri steril kemudian spons dibilas. Setelah dibilas, dengan teknik aseptik spons dihomogenisasi dengan mencampurkan $100 \mathrm{ml}$ air laut steril didalam ependorf kemudian digerus menggunakan mortar. Selanjutnya ditumbuhkan kedallam media NB. Pertumbuhan bakteri pada media nutrient broth ditandai dengan adanya kekeruhan dalam media. Selanjutnya dilakukan pengenceran dengan cara: $1 \mathrm{ml}$ air laut hasil homogenisasi dimasukkan ke dalam $9 \mathrm{ml}$ air laut steril pada tabung reaksi kemudian dilanjutkan ke tabung kedua hingga tabung keempat sehingga konsentrasi menjadi $10^{-4}$. Larutan dengan konsentrasi $10^{-1}, 10^{-2}, 10^{-3}$ dan $10^{-4}$ kemudian diinokulasi ke dalam media nutrient Agar yang diperkaya $2 \%$ spons dengan menggunakan metode gores sinambung dan swab/menyapu (Wntania, dkk. 2016). Tahapan dilakukan dengan cara aseptik. Sampel diinkubasi selama \pm $24-48$ jam pada suhu $37^{\circ} \mathrm{C}$. Pertumbuhan bakteri ditandai dengan adanya pertumbuhan koloni bebas dalam media NA.

Pemurnian dilakukan untuk memisahkan isolat bakteri yang berlainan jenis dan masih terdiri dari banyak koloni sehingga didapat isolat tunggal dari bakteri (Pastra dan Surbakti, 2012). Isolat bakteri tunggal dipisahkan berdasarkan karakteristik morfologinya mulai dari ukuran, bentuk, warna, dan elevasi.

\section{Karakterisasi Morfologi Bakteri Simbion}

Berdasarkan karakterisais morfologinya dengan memperhatikan ukuran, bentuk, warna, dan elevasi kemudian ditentukan dengan mengacu pada Cappucino dan Sherman (1998).

\section{HASIL DAN PEMBAHASAN}

Baerdasarkan hasil identifikasi spons dari peraran Malalayang Sulawesi Utara. Spons teridentivikasi mirip dengan Cribocalina sp. Menurut Schmidt (1870) dalam WoRMS (2019).

Bakteri yang bersimbiosis dengan spons yang menyerupai Cribochalina $\mathrm{sp}$ berhasil ditumbuhkan pada media NB yang ditandai dengan kekeruhan media setelah media yang diinokulasi dengan sampel diinkubasi pada suhu $37^{\circ} \mathrm{C}$ selama 48 jam. Bakteri yang tumbuh juga berhasil ditumbuhkan kembali pada media NA yang diperkaya dengan cara goresan sinambung/kuadran.

Abubakar, $\quad d k k$. memperoleh 138 isolat dari hasil isolasi bakteri yang memiliki potensi anti mikroba dari spons Jaspis sp. yang diisolasi dari bagian endovid didapati 70 isolat dan 68 isolat dari bagian permukaan.

Ginting, dkk. 2019 juga berhasil menisolasi 5 isolat bakteri simbion dengan 
alga merah dari perairan Tongkaina dimana ke lima isolat memiliki karakteristik morfologi yang berbeda-beda.

Berdasarkan hasil pengamatan morfologi, didapatkan 5 isolat bakteri simbion spons yang menyerupai Cribochalina sp.

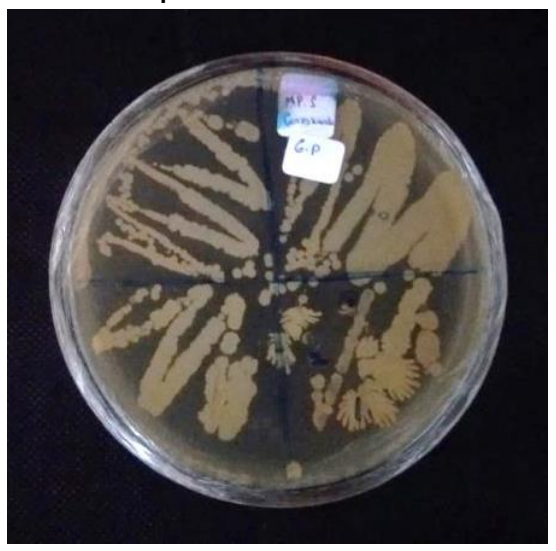

Gambar 2. Hasil isolasi bakteri simbion spons yang tumbuh dalam media NA.

Kelima isolat bakteri ini ditumbukan pada media diperkaya yang mengandung spong. Oleh sebab itu diduga kuat bahwa bakteri ini bisa hidup dengan spons sebagai habitatnya karena mengandung nutrien yang ada pada inangnya.

Media yang diperkya ini mengandung $2 \%$ spons, oleh sebab itu bakteri iolasi yang didapat merupakakn bakteri yang berada atau hidup bersimbion dengan spons yang menyerupai Cribochalina sp (Tabel 1). Hal ini disebabkan karena kepadatan dan kerapatan sel bakteri serta ketersediaan nutrisi dalam media (Willey, dkk. 2008).

Wantania, dkk. (2016). Melaporkan Bakteri simbion spons Facaplisynopsis sp. dan Agelas sp. dari periaran Tongkaina Sulawesi Utara juga berhasil diisolasi. Dan diperoleh sepuluh isolat bakteri dengan karaktersitik morfologi yang bervariasi.

Tabel 1. Karakteristik Isolat Bakteri dari Spons yang menyerupai Cribochalina sp. Cribochalina sp.

\begin{tabular}{|l|c|c|c|c|}
\hline \multirow{2}{*}{ Kode Isolat } & \multicolumn{4}{|c|}{ Karakteristik Koloni } \\
\cline { 2 - 5 } & Bentuk & Warna & Tepian & Elevasi \\
\hline SS.1 & Filamentous & Putih & Filiform & Flat \\
\hline SS.2 & Circular & Putih & Entire & Raised \\
\hline SS.3 & Rhizoid & Putih & Filiform & Flat \\
\hline SS.4 & Circular & Coklat & Undulate & Raised \\
\hline SS.5 & Circular & Putih & Entire & Flat \\
\hline
\end{tabular}


Berdasarkan tabel 1, isolat bakteri SS.1, SS.2, SS.3, SS.4 dan SS.5 memiliki koloni yang dominan berbentuk circular dengan warna dominan adalah putih akan tetapi memiliki tepian dan elevasi yang berbeda. Hal ini menandakan bahwa setiap bakteri yang bersimbion dengan spons memiliki karakteristik dan jenis yang berbeda.

Rangian, dkk. 2018. Melaporkan bakteri simbion spons Facaplysynopsis sp. dari perairan tongkeina, sulawesi utara berhasil diidentifikasi molekuler. Bakteri simbion spons yang berasal dari pantai ujung piring jepara telah berhasil diisolasi. diperoleh 15 isolat yang merupakan penghasil enzim ekstraseluler yang telah diidentifikasi sebagai Bacillus sp., Acinetobacter sp., dan Pseudomonas sp. (setyati,dkk. 2016).

Setiawan, (2016) berhasil mengisolasi bakteri simbion dari karang lunak dan nematoda yang mana hasil yang dilaporkan umumnya merupakan bakteri jenis Bacillus toyonensis strain BCT 7112, dan bakteri Bacillus cereus ATCC 14579 dengan presentase kemiripan 98\%.

Widiyaningsih, dkk. (2018) melaporkan menisolasi 10 isolat bakteri simbion dari karang lunak Sinularia sp, dimana hanya satu isolat bakteri saja yang teridentifikasi memiliki kekerabatan dengan Pseudomonas stutzeri .Isolat bebas yang telah dikarakterisasi ditumbuhkan ke dalam media miring untuk dijadikan stok bakteri terlihat pada Gambar 3.

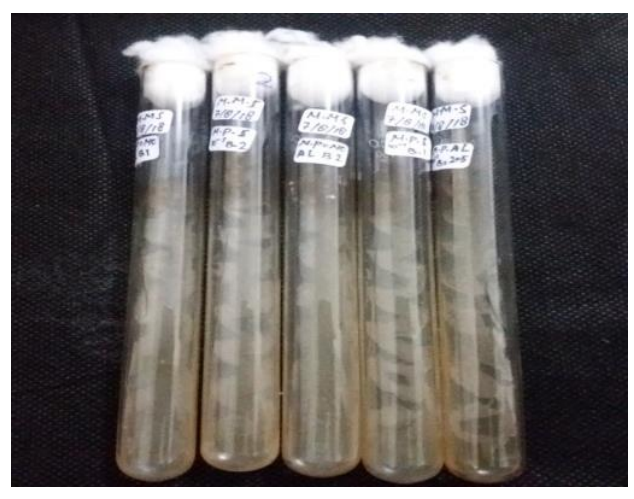

Gambar 3. Pertumbuhan Koloni Bakteri pada Agar Miring

\section{KESIMPULAN}

Bakteri simbion spons dari perairan Malalyang yang berhasil diisolasi berjumlah lima isolat. Kelima isolat bakteri (SS.1, SS.2, SS.3, SS.4 dan SS.5) yang bersimbion dengan spons Cribochalina sp dari Teluk Manado Sulawesi Utara memiliki karakteristik yang umumnya berwrna putih dan kuning dengan bentuk circular.

\section{Daftar Pustaka}

Abubakar, H., Wahyudi, T. A., Yuhana, M. 2011. Skrining Bakteri yang Berasosiasi dengan Spons Jaspis sp. Sebagai Penghasil Senyawa Antimikroba. Jurnal Ilmu Kelautan 16(1): 35-40.

Cappucino, J. G., and Sherman N. 1998. Microbiology, A Laboratory Manual. Benjamin/Cummings Science Publishing, California.

Ginting, E.L,. Rangian, L,. Wantania, L,. Wullur, S. 2019. Isolasi Bakteri Simbion Alga Merah Dari Perairan Tongkeina, Sulawesi Utara. Jurnal IImiah Platax. 7(2):394-400.

Lee, Y.K., Jung H.L., and Hong K.L., 2001. Microbial Symbiosis in Marine Sponges, The Journal of Microbiology, 39(4) : 254264.

Pastra, D. A., Melki dan Surbaktii A. 2012. Penapisan Bakteri yang Bersimbiosis dengan Spons Jenis Aplysina sp sebagai Penghasil Antibakteri dari Perairan Pulau Tegal Lampung, Jurnal Maspari, 4(1),7782.

Rangian, L., Ginting, E. L., Wullur, S., Kaligis, E., Tilaar, S., dan Tumbol, R. 2017. Amplifikasi Isolat Bakteri SF1 Simbion Spons Facaplysynopsis sp. Dari Perairan 
Tongkeina, Sulawesi Utara. Universitas Sam Ratulangi, Manado.

Setyati, A. W,. Habibi, S. A,. Subagiyo,. Ridlo. A,. Nirwani, S,. Pramesti, R,. 2016. Skrining Dan Seleksi Bakteri Simbion Spons Penghasil Enzim Ekstraseluler Sebagai Agen Bioremediasi Bahan Organik Dan Biokontrol Vibriosis Pada Budidaya Udang. Jurnal Kelautan Tropis. 19(1):11-20.

Setiawan, B,. 2016. Karakterisasi Fisiologi Dan Molekuler Bakteri Simbion Nematoda Entomopatogen Berdasarkan Sekuen Gen Pengkode 16s Rrna Dari Bromo Kabupaten Probolinggo. Program Studi Magister Biologi Fakultas Matematika Dan IImu Pengetahuan Alam Universitas Jember. Tesis.

Sulasi, F., Mangindaan, R. E. P., Losung, F. 2013. Lektin Dari Spons Cliona Varians Asal Perairan Malalayang Manado. Universitas Sam Ratulangi, Manado.

Van Soest, R. W. M. 1989. The Indonesian Sponge Fauna: A status Report.
Netherland Journal of Sea Research. Hal. 223-230. Netherland.

Wantania, L. L., E. L. Ginting., S. Wullur. 2016. Isolasi Bakteri Simbion Dengan Spons dari Perairan Tongkeina Sulawesi Utara. Jurnal LPPM Bidang Sains dan teknologi. 3(1): 57-65.

Widyaningsih, S,. and Nor Sa'adah. 2018. Baktei Simbion Karang Lunak Sinularia sp. Sebagai Agen Antibakteri. Jurnal Kelautan Tropis. 21(1):61-64.

Willey, J. M., Sherwood L.M., and Woolverton C, J. 2008. Prescott, Harley, and Klein's Microbiology seventh Edition. The McGraw-Hill Companies, Inc. New York. Hal 101-149.

WoRMS (World Register of Marine Species). (2019). Marine Species. Tersedia: http://www.marinespecies.org/. (Diakses tanggal 18 Juni 2019). 